\section{Asystole and hypomagnesaemia during recovery from diabetic ketoacidosis}

Magnesium is the second most abundant intracellular cation and may become depleted during diabetic ketoacidosis. ${ }^{1}$ This ion is largely ignored, however, in the management of this condition even though its depletion causes profound disturbance of cellular metabolism. ${ }^{1}$ A patient with severe, untreated diabetes is described who suffered a sudden asystolic cardiac arrest while improving on conventional treatment. The arrest and subsequent dysrrhythmias were associated with a low serum magnesium concentration and recovery occurred after treatment with intravenous magnesium sulphate.

\section{Case report}

A 13-year-old girl was admitted with a five-month history of thirst, polyuria, and a weight loss of nine kilograms. She was unconscious with a pulse rate of 120 per minute and a systolic blood pressure of $70 \mathrm{~mm} \mathrm{Hg}$. She had a metabolic acidosis, with a pH of 6.8, and the remaining biochemical features are shown in the table. The patient was treated with intermittent doses of soluble insulin, replacement of electrolytes and fluid as indicated by biochemical estimations (see table), and ampicillin. In all, seven litres of $0.9 \%$ saline; three litres of $5 \%$ dextrose; $400 \mathrm{mmol}$ (mEq) of sodium bicarbonate; $330 \mathrm{~mol}(\mathrm{mmEq})$ of potassium chloride; and 140 units of soluble insulin were given over the first 21 hours. At this stage the blood sugar concentration was $13.3 \mathrm{mmol} / \mathrm{l}(240 \mathrm{mg} / 100 \mathrm{ml})$, $\mathrm{pH} .7 \cdot 35$, with satisfactory electrolyte concentrations. She wes lucid; her blood pressure was $110 / 70 \mathrm{~mm} \mathrm{Hg}$, respiratory rate 14 , and pulse 90 with occasional irregularity. No electrocardiograph was obtained at this stage and sudden asystolic cardiac arrest occurred $1 \frac{3}{4}$ hours later. After five minutes' external cardiac massage, intravenous dexamethasone, adrenaline, and isoprenaline spontaneous cardiac activity returned with ventricular tachycardia followed by supraventricular tachycardia. The patient regained consciousness and her blood pressure rose to $110 / 60 \mathrm{~mm} \mathrm{Hg}$. Twenty minutes later the heart rate dropped to 40 beats per minute with idioventricular rhythm and spontaneous respiration ceased. Respiration was maintained using a Cape ventilator. The serum magnesium concentration was $0.3 \mathrm{mmol} / 1(0.6 \mathrm{mEq} / \mathrm{l})$ (normal range 0.7 to $1.0 \mathrm{mmol} / 1(1.4-2.0 \mathrm{mEq} / \mathrm{l})$ ).

Over the next six hours $60 \mathrm{mmol}$ of magnesium as the sulphate salt was given by intravenous infusion. Immediately after the respiratory arrest there were multifocal ectopic beats, short runs of ventricular and supraventricular tachycardia alternating with sinus rhythm. Antiarrhythmic agents were not used and the rhythm settled to sinus rhythm, rate 70-100 beats/min with infrequent ventricular ectopic beats $(0-4 / \mathrm{min})$ within four hours of starting the magnesium sulphate. Her subsequent recovery was uneventful and she was discharged home four weeks later on 26 units of isophane insulin.

\section{Discussion}

Apart from the direct effects of hypomagnesaemia, the available evidence suggests that in the presence of important magnesium depletion ionic imbalance of sodium and potassium occurs owing to the failure of cell-wall pumping mechanisms. ${ }^{1}$ Against this background of imbalance it is reasonable to postulate that cardiac arrhythmias could occur especially in the state of flux during the management of ketoacidosis. I could find no reference to cardiac arrythmias occurring solely as a result of hypomagnesaemia, although it does cause characteristic electrocardiograph changes and may potentiate the toxic effects of digoxin on the myocardium. ${ }^{2}$ The addition of magnesium to the treatment of ketoacidosis is not a new concept ${ }^{2}$ and this report suggests that it should be considered if cardiac dysrrhythmia or clinical evidence of hypomagnesaemia ${ }^{3}$ occurs. The clue in the case described lies perhaps in the irregular pulse recorded shortly before the arrest.

I thank Dr P R Duncan for his permission to publish details of a patient under his care and Miss B M Evans for secretarial help.

1 Walker, W E L, and Vallee, B L, New England fournal of Medicine, 1968, 278, 658,712, 722

${ }^{2}$ Miller, H, and Daley, H, Progress in Clinical Medicine. Edinburgh, Churchill Livingstone, 1971 .

${ }^{3}$ Hanna, S, et al, Lancet, 1960, 2, 172.

(Accepted 1 December 1976)

Department of Medicine, Victoria Hospital, Blackpool

J K MCMULLEN, MB, MRCP(UK), medical registrar

Results of biochemical investigations

\begin{tabular}{|c|c|c|c|c|c|c|c|c|c|c|c|}
\hline \multirow{2}{*}{$\begin{array}{c}\text { Time } \\
\text { (hours after } \\
\text { admission) }\end{array}$} & \multicolumn{5}{|c|}{ Blood gases } & \multicolumn{4}{|c|}{ Serum electrolyte concentrations $(\mathrm{mmol} / \mathrm{l})$} & \multirow{2}{*}{$\begin{array}{c}\text { Blood } \\
\text { Glucose } \\
\text { (mmol/1) }\end{array}$} & \multirow{2}{*}{$\underset{\substack{\text { magnesium } \\
\text { (mmol/l) }}}{\text { Serum }}$} \\
\hline & $\mathrm{pH}$ & $\begin{array}{r}\mathrm{PCO}_{2} \\
(\mathrm{kPa})\end{array}$ & $\begin{array}{c}\text { Standard } \\
\text { bicarbonate } \\
(\mathrm{mmol} / \mathrm{l})\end{array}$ & $\begin{array}{c}\begin{array}{c}\text { Base } \\
\text { excess } \\
(\text { mmol/1) }\end{array} \\
\end{array}$ & $\begin{array}{r}\mathrm{Po}_{2} \\
(\mathrm{kPa})\end{array}$ & Urea & $\mathrm{Na}$ & $\mathbf{K}$ & $\mathrm{Cl}$ & & \\
\hline $\begin{array}{c}0 \\
5 \\
9 \\
21 \\
23 \mathrm{~h} 15 \mathrm{~min} \\
31 \mathrm{~h} 50 \mathrm{~min}\end{array}$ & $\begin{array}{l}6.880 \\
6.990 \\
7.150 \\
7.350 \\
7.510 \\
7 \cdot 315\end{array}$ & $\begin{aligned}<1 \\
4.39 \\
3.99 \\
5.05 \\
3.72 \\
6.12\end{aligned}$ & $\begin{array}{l}<6 \\
8.5 \\
14.5 \\
22.0 \\
24.0 \\
22.0\end{array}$ & $\begin{array}{c}>-22 \\
-22.0 \\
=12.0 \\
=4.0 \\
=0.5 \\
=3.0\end{array}$ & $\begin{array}{l}19 \cdot 3 \\
11 \cdot 3 \\
12 \cdot 0 \\
12 \cdot 0 \\
20 \cdot 6 \\
27 \cdot 3\end{array}$ & $\begin{array}{l}18.8 \\
15.5 \\
15.3 \\
15.0 \\
13.3 \\
10 \cdot 2\end{array}$ & $\begin{array}{l}134 \\
137 \\
134 \\
138 \\
136 \\
140\end{array}$ & $\begin{array}{l}5 \cdot 0 \\
2 \cdot 8 \\
2 \cdot 5 \\
3 \cdot 4 \\
3 \cdot 5 \\
3 \cdot 1\end{array}$ & $\begin{array}{r}106 \\
105 \\
103 \\
101 \\
97 \\
108\end{array}$ & $\begin{array}{r}23 \cdot 9 \\
21 \cdot 1 \\
20 \cdot 0 \\
13 \cdot 3 \\
7 \cdot 8 \\
25 \cdot 0\end{array}$ & $\begin{array}{l}\bar{Z} \\
\overline{\overline{0}} \\
1 \cdot 15\end{array}$ \\
\hline
\end{tabular}

Conversion: $S I$ to traditional units- $P C O_{1}$ and $\mathrm{Po}_{2}: 1 \mathrm{kPa}=7.5 \mathrm{~mm} \mathrm{Hg}$ Serum urea: $1 \mathrm{mmol} / 1 \approx 6 \mathrm{mg} / 100 \mathrm{ml}$. Serum sodium, potassium, chloride, standard bicarbonate and base excess: $1 \mathrm{mmol} / 1=1 \mathrm{mEq} / \mathrm{l}$. Blood glucose: $1 \mathrm{mmol} / 1=18.0 \mathrm{mg} / 100 \mathrm{ml}$. Serum magnesium: $1 \mathrm{mmol} / 1=2 \mathrm{mEq} / 1$. 